\title{
Inclusive Growth in the Middle East and North Africa: Before and After the Global Financial Crisis*
}

\author{
Orta Doğu ve Kuzey Afrika'da Kapsayıcı Büyüme: Küresel Finansal Krizden Öncesi ve Sonrası \\ Ece Handan Güleryüz ${ }^{{ }^{* * *}}$ \\ ${ }^{a}$ Dr. Öğr. Üyesi, Marmara Üniversitesi, İktisat Fakültesi, İktisat Bölümü, 34722, İstanbul/Türkiye. \\ ORCID: 0000-0003-0692-9112
}

\section{MAKALE BİLGİSİ \\ Makale Geçmiși: \\ Başvuru tarihi: 26 Kasım 2020 \\ Düzeltme tarihi: 17 Nisan 2021 \\ Kabul tarihi: 18 Mayıs 2021}

Anahtar Kelimeler:

Kapsayıcı Ekonomik Büyüme,

Küresel Finansal Kriz,

MENA Ülkeleri

\section{A R T I C LEINFO}

\section{Article history:}

Received: November 26, 2020

Received in revised form: April 17, 2021

Accepted: May 18, 2021

\section{Keywords:}

Inclusive Economic Growth,

Global Financial Crisis,

MENA Countries
ÖZ

Bu çalışmada, Küresel Finansal Kriz öncesi ve sonrasında 16 MENA ülkesinde kapsayıcı büyümeyi etkileyen makroekonomik temeller ve yapısal faktörler incelenmiştir. Panel veri sabit etkiler modeli iki zaman diliminde kullanılmaktadır: 1996-2007 ve 2008-2016. Kapsayıcı büyümenin bir ölçüsü, ekonomik büyüme ile gelir eșitsizliğini bütünleștirerek tanımlanmıștır. Bu șekilde, kiși bașına düșen GSYH büyüme oranının ve Gini katsayısındaki değişimin göreli etkileri hesaba katılmıştır. MENA bölgesinde çevresel bozulma, makroekonomik istikrar, mali disiplin, küreselleşme, beşeri sermaye, ortalama yaşam süresi ve teknolojik gelişme gibi çok çeşitli faktörlerin kapsayıcı büyüme performansını önemli ölçüde etkilediği görülmektedir.

\section{A B S T R A C T}

In this study the macroeconomic fundamentals and structural factors which affect inclusive growth in 16 MENA countries before and after the Global Financial Crisis are investigated. A panel data fixed effects model is used in two time periods: 1996-2007 and 2008-2016. A measure of inclusive growth is defined by integrating economic growth and income inequality. In this way, the relative impacts of GDP per capita growth rate and change in Gini coefficient are accounted for. A wide range of factors such as environmental degradation, macroeconomic stability, fiscal discipline, globalization, human capital, life expectancy, and technological development appear to significantly affect inclusive growth performance in the MENA region.

\section{Introduction}

Economic growth has increased and absolute poverty has decreased at extensive degrees over the last 30 years. Nevertheless, the high economic growth rates achieved have not necessarily transformed into a more equal income distribution and sufficient provision of the necessities for the low-income groups in the society (Stiglitz, 2012: 7174). The growth achieved through increases in GDP levels appears not to be sufficient anymore by itself to guarantee a developed and equitable national economy. Researchers and policy makers have acknowledged the critical importance of transforming national income into the overall society's well-being through higher income equality, good governance, and sustainable and high economic growth. Therefore, the focus of policy makers and researchers has recently started to shift to the subject of inclusive economies and inclusive economic growth.

In spite of the rapidly growing body of policy studies and literature on the topic of inclusive growth, there is still no clear agreement on the definition, measurement and determinants of inclusive economic growth (Ianchovichina and Lundstrom, 2009: 2-6; Thorat and Dubey, 2012: 45).

* This paper was presented at the TED University Trade Research Center (TEDUTRC). Emerging Markets: Recent Challenges International Conference of TRC in Ankara, Turkey on June 13-14 2019, Middle East Economic Association (MEEA) 39 ${ }^{\text {th }}$ MEEA/ASS Annual Meeting in Atlanta, the United States on January 4-7 2019, and ICE-TEA 2018 International Conference on Economics - Turkish Economic Association in Antalya, Turkey on November 1-3 2018.

**Sorumlu yazar/Corresponding author

e-posta: ece.guleryuz@ marmara.edu.tr 
For instance, some studies do not stress any difference between pro-poor growth and inclusive growth (Ranieri and Ramos, 2013: 4-10). On the other hand, some other studies draw distinctive differences between the two concepts. The World Bank report, argues that while absolute pro-poor growth concentrates more on growth poverty statistics, and income distribution issues inclusive economic growth focuses on improvements in productivity and labor market, high economic growth, and poverty reduction (World Bank, 2009:1-3).

We aim to answer the research question of what the macroeconomic, socioeconomic and institutional factors which affect inclusive economic growth in the MENA region before and after the Global Financial Crisis are. We are interested to find out which factors contribute to economic inclusiveness in a group of MENA countries between 1996 and 2016 with a comprehensive perspective. Notwithstanding the differences in development levels, many countries have to solve the problem of distributing the economic wealth generated more equally in the society. In line with this issue, the thrust of related research has started to shift from primarily using GDP per capita as the statistic measuring economic growth to exploring the dynamics of inclusive economic growth in recent years. As Alvaredo et al. (2019: 690-691) found out that the Middle East was the world region which experienced highest income inequality during the period 1990-2016 that coincided with the years both before and after the Global Financial Crisis, we have also acknowledged the crucial significance of inclusive economic growth in MENA region, and detected an insufficiency in the number of studies written about economic inclusiveness in MENA countries. Moreover, as discussed in the Literature Review section, most of the related studies concentrate on the relationship between inclusive economic growth and another variable or a set of few variables, and they provide a narrow empirical perspective. Thus, in the literature, there has been a deficiency of studies written about inclusive economic development in MENA region. Due to these reasons and in order to fill the gap in the literature with a work that includes a more comprehensive analysis about the dynamics of inclusive economic growth in MENA countries, we have decided to work on this subject.

In this paper, we use the conceptualization of inclusive economic growth which integrates economic growth and income inequality (Anand et al., 2013: 5-8). Our primary aims are to build a multidimensional framework and analyze macroeconomic, socioeconomic, and institutional determinants of inclusive economic growth in MENA countries before and after the Global Financial Crisis, and so fill a crucial gap in the related literature and provide some policy recommendations to promote economic inclusiveness in the MENA region.

In this study, we examine the determinants of inclusive economic growth in 16 MENA region countries before and after the Global Financial Crisis. We work to assess the inclusiveness of growth in the MENA region from a comprehensive perspective. We investigate the effects of macroeconomic stability, environment, globalization, fiscal consolidation, education, labor market, social development, technological advancement, and institutional quality factors on inclusive economic growth. Our main objective in this study is to provide a plausible assessment about the proximate determinants of inclusive growth in the MENA region before and after the Global Financial Crisis. To the best of our knowledge this study is one of the first attempts to analyze the determinants and evolution of inclusive growth before and after the Global Financial Crisis in the MENA region countries.

\section{Literature Review}

Inclusive growth has recently become a popular subject in the Development Economics literature. Countries all over the world regardless of their income levels often face challenges in terms of spreading economic growth to broad segments of society. The studies done on this subject substantially vary in terms of methodology, time period and country coverage. Furthermore, they have not reached a consensus over a common set of determinants of inclusive growth. There are studies that analyze economic development and related issues in the MENA region from various perspectives. In some studies, thorough overviews about the important strength and weakness areas for sustainable and inclusive development in MENA countries were provided (O'Sullivan et al., 2011:46-50). Moreover, inequality and pro-poor growth in the MENA region were examined (Cherkaoui et al., 2009: 2-11; Ncube et al., 2014: 435-437). Some studies discussed MENA countries' inclusive growth challenges in relation to the specific characteristics of the region such as natural resources and inclusive economic growth (Arezki and Nabli, 2012: 4-6), the impact of Islamic Finance on economic development's inclusiveness (Nabi, 2013: 3-5), and relationship between the region's labor market dynamics and inclusive economic growth (Hakimian et al, 2014: 3-7).

There are some papers which adopt a collective approach to the analysis of inclusive economic growth, similar to the one we use in this paper. Vellala et al. (2014: 232-234) proposed a theoretical model for inclusive economic growth in the Indian economy. This model identified human development, basic socio-economic infrastructure, governance, poverty reduction, economic growth, productive employment, gender equity, and inequality reduction as the eight pillars responsible for generating inclusive economic growth. In another related study done for the Philippines' economy Ali and Son (2007: 11-12) built a social opportunity function of the level of opportunities and the distribution of opportunities in the society which determined inclusive growth. In a crosscountry work, Dinda (2014: 878) found out that increases in the levels of human capital and social capital positively affected inclusive growth.

In recent years, an inclusive growth measure was introduced by incorporating per capita economic growth rates and income inequality levels of countries, and then the determinants of economic inclusiveness which was defined by this composite measure were investigated. In the related estimation results, both for emerging and advanced economies it was found that there were positive relationships between macroeconomic stability, fiscal discipline, human capital accumulation, trade openness, investment, and inclusive economic growth (Anand et al., 2013: 5-13). Furthermore, income concentration degrees in a group of Middle East countries were estimated during the 
period 1990-2016. It was argued that Middle East turned out to be the most unequal region worldwide, and it suffered from both income inequality between oil-rich and high population countries and within countries (Alvaredo et al., 2019: 690-691).

There are studies that question the long-acknowledged usage of GDP per capita as the measure of economic development. In some studies, a welfare statistic which integrated leisure, mortality, consumption, and inequality was proposed to provide a more thorough insight compared to what GDP per capita, as a macroeconomic measure, could offer about the general well-being of people in a country (Jones and Klenow, 2016: 2430). In another work, the evolution of real median incomes and income inequality between 1980 and the Great Recession were investigated in OECD countries. It was found that changes in Gini coefficient and median income were negatively correlated, and this correlation was statistically significant (Thewissen et al., 2015: 3-7).

Some academic works chose to focus on single country or country groups' experiences on inclusive economic growth. Taskin (2014: 34-38) examined the degree of inclusiveness in Turkish Economy's macroeconomic performance. In the study, it has been suggested that Turkish Economy had inclusive growth performance between 2002-2011.In another work; between the four rich countries which are the U.S., the U.K., France and Norway, it has been claimed that the U.S. had the most poorly performing to achieve more inclusive economic growth levels (Roser and Thewissen, 2017: 1).

When the related literature is examined, it is found that a wide spectrum of factors has been highlighted to have an effect on inclusive economic growth. For instance, Rodrik (2014: 9-12) emphasized the importance of improving the domestic market economies of developing countries to achieve sustainable growth rates by maintaining a more equitable income distribution, human capital accumulation, and better quality political, regulatory, legal institutions. Moreover, in an OECD (Organization for Economic Cooperation and Development) report, the importance of including education, environmental and political economy aspects into inclusive economic growth measurements is also discussed (Boarini et al., 2015: 6-16).

There are various studies written investigating the relationships between inclusive economic growth, and the macroeconomic, socioeconomic and institutional factors we use in the estimations. Asongu and Odhiambo (2020: 18) found a negative correlation between environmental degradation (measured with $\mathrm{CO}_{2}$ emissions) and inclusive human development for 44 sub-Saharan African countries for the period 2000-2012. Abdu et al. (2018: 382), and Aoyagi and Ganelli (2015: 29-30) argued that a higher level of macroeconomic stability caused a higher degree of inclusive economic growth in Nigeria and a group of Asian countries, respectively. On the other hand, Zulfiqar (2018: 21) concluded that fiscal discipline which worked through government expenditure and tax policy was not effective in promoting inclusive growth in Pakistan during the period 1980-2015.

Some authors emphasized the positive influence of higher education on inclusive economic growth in developing countries such as Philippines, Bangladesh, and Nigeria (Canlas, 2016: 3, Islam, 2014: 2-3, Oluwadamilola et al., 2018: 4088, Okafor et al., 2016: 107). Furthermore, there are also studies which focus on the positive relationship between high-technology exports, trade openness and economic inclusiveness in emerging economies (Arabiyat et al., 2020: 121, Agarwal, 2012: 1864, Nguyen and Pham, 2020: 175). Regarding the nexus between institutional quality and inclusive growth, Kumah and Sandy (2013: 758) argued that better institutions supported economic inclusiveness in low-income countries. Gyamfi et al. (2019: 1-3) and Yinusa et al. (2020: 182) found out that a higher institutional quality enhanced the positive impact of financial development on inclusive economic growth in 48 African countries and in Nigeria, respectively.

\section{Empirical Analysis}

\subsection{Data Dynamics and Methodology}

We investigate the macroeconomic fundamentals and structural factors which affect inclusive growth in 16 MENA countries. We divide the estimation period into two parts: 1996-2007 which refers to the period before the Global Financial Crisis, and 2008-2016 which refers to the period after the Global Financial Crisis periods. In order to account for the unobserved country specific, individual effects we use panel data and the fixed effects model. There are a couple of important advantages of panel data. Panel data helps to control for heterogeneity of individual countries over time, and so it helps to obtain an unbiased estimation. It also reduces biases which can be caused by aggregation. Furthermore, panel data provides more degrees of freedom, more variability, less collinearity among dependent variables, more efficiency, and a better estimation to examine the dynamics of change of variables over time compared to time series or cross-sectional data. We also validate the use of fixed effects model over possible alternative models. The F test results indicate the existence of significant country level effects, thus using a pooled OLS model is not appropriate. Moreover, the Hausman test shows the fixed effects model is more appropriate compared to the random effects model.

The data source for macroeconomic and development indicators is the World Bank's World Development Indicators data set. We use the Worldwide Governance Indicators' six measures (voice and accountability, political stability and absence of violence, government effectiveness, regulatory quality, rule of law, and control of corruption) to assess the institutional quality which can be effective on inclusive growth performance of MENA countries. We obtain the Gini coefficients data from Alvaredo et al. paper (Alvaredo et al., 2019: 710-711). They collect the income distribution data from countries' household surveys. Nevertheless, household surveys are done only in specific years and this brings about a missing data situation. To resolve this issue, they use the distribution data of the closest available years for the years with no income distribution statistics. We acknowledge that this may limit the contribution of income inequality to the measurement of the evolution of inclusive growth to a degree. Table 5 in the appendix provides a full list of the variables used in estimations. 
Anand et al. (2013: 5-9) generated a measure of inclusive growth by integrating the relative impacts of economic growth and income distribution equality. They used a differentiation function which decomposed inclusive economic growth into growth and an income equity index. We use a similar decomposition method to define a statistic of inclusive economic growth. Instead of an income equity index we use income inequality measured by Gini coefficient due to data unavailability of an income equity index for the countries in our sample. Therefore, we can express the measure of inclusive growth as the following;

$$
\begin{aligned}
& \text { inclusive economic growth }=\frac{\mathrm{d}(\text { gdp per capita })}{\text { gdp per capita }}+ \\
& (-1)\left[\frac{\mathrm{d} \text { (gini coefficient) }}{\text { gini coefficient }}\right]
\end{aligned}
$$

, where the letter $\mathrm{d}$ is the differentiation function symbol. Equation (1) is a differentiation function, and it demonstrates the decomposition of inclusive economic growth into economic growth and change in income inequality. We use GDP per capita growth rate and the change in Gini coefficient to measure the components of economic growth and change in income inequality, respectively. When the Gini coefficient increases this indicates an increase in income inequality which negatively affects inclusive economic growth, so in order to quantitatively show this economic impact in equation (1), we multiply the second component with minus 1 .

\subsection{Estimation Results}

The general benchmark equation we use can be written as the following;

$y_{i t}=\beta_{0}+\beta_{1} x_{i t}+u_{i}+\varepsilon_{i t}$,

where $y_{i t}$ is inclusive growth rate, $x_{i t}$ is the vector of independent variables which vary over countries and years, $\mathrm{u}_{\mathrm{i}}$ is the individual country level effect, and $\varepsilon_{i t}$ is the disturbance term. We initially estimate the models with year fixed effects. Since these time effects mostly appear statistically insignificant, ultimately we use one-way fixed effects model in the estimations. All the models are estimated with robust standard errors. In both tables 1 and 2 starting from estimation (3) we first include the six institutional quality indicators one by one to examine their individual effects on inclusive growth, in estimation (9) we include the six indicators' comprehensive average index (wgi average in the estimation tables), and in estimation (10) we control all the six variables simultaneously.

\subsubsection{Before the Global Financial Crisis}

Table 1 reports the estimation results during the period 1996-2007 which is specified as the before Global Financial Crisis period. Even though investment positively affects inclusive growth this positive influence becomes statistically significant at 5\% level only after including tertiary education into the estimation. Environmental degradation which is approximated by the rise in $\mathrm{CO}_{2}$ emissions deteriorates inclusive economic growth performance. Increases in lagged GDP per capita that measures conditional convergence, government expenditure which is used to assess fiscal consolidation, and inflation rate that is controlled as an indicator for macroeconomic stability negatively impact inclusive growth. FDI shows a negative effect on inclusive economic growth with $15 \%$ significance in some estimations.

Other proposed macroeconomic and socioeconomic determinants such as trade volume (openness), education (measured by secondary and tertiary education levels), life expectancy, domestic credit to private sector, and high technology goods exports which measures relative technological advancement positively affect inclusive growth rate. All the six institutional quality indicators and their comprehensive average index appear statistically insignificant.

\subsubsection{After the Global Financial Crisis}

Table 2 shows the estimation results during the period 20082016. During and after the Global Financial Crisis, consistent with conditional convergence theory lagged GDP per capita negatively affects inclusive growth at $1 \%$ significance level. Deterioration in environmental quality measured by the increase in $\mathrm{CO}_{2}$ emissions again worsens inclusive growth performance within the MENA countries. Increases in government expenditure and inflation rate which refer to low fiscal consolidation performance and macroeconomic volatility respectively, negatively impact inclusive growth after the Global Financial Crisis although their effects are now statistically insignificant.

A rise in unemployment rate which indicates a decrease in labor market stability diminishes inclusive growth rates. Similar to the period before the Global Financial Crisis, increases in secondary education, tertiary education, life expectancy, and high technology goods exports positively affect inclusive growth rates. Furthermore, after the Global Financial Crisis improvements in voice and accountability which accounts for the perceptions about citizens' capability to participate in electing politicians to the office through democratic, free and transparent processes, also about freedom of expression, freedom of association, and freedom of media positively impact inclusive growth with a $10 \%$ statistical significance.

\subsection{Robustness Checks}

\subsubsection{Inclusive Growth during 1996-2016}

As a first round of robustness check we gather the two samples into one bigger sample and estimate the same models in the period 1996-2016. The estimation results can be seen in table 3 in the appendix. In this way, we work with a higher number of observations and a longer time period. Increases in $\mathrm{CO}_{2}$ emissions, past period's GDP, government expenditure, and inflation negatively affect inclusive economic growth with a statistical significance. On the other hand, trade, secondary education, life expectancy, high technology exports, and tertiary education are found to be positively and significantly correlated with inclusive growth. Moreover, improvements in government effectiveness, regulatory quality and overall institutional quality positively and significantly affect inclusive economic growth.

We additionally include natural resource rents in the estimations (the results are not reported in the paper) since the MENA region is rich in natural resources and natural 
resource products significantly contribute to national income generation in some region countries. It is found that the effects of other indicators on inclusive growth do not change drastically after controlling for natural resource rents. Before the Global Financial Crisis (1996-2007), natural resource rents appear to positively influence inclusive growth, nonetheless this influence is not statistically significant. On the other hand, after the Global Financial Crisis (2008-2016) natural resource rents are found to be negatively correlated with inclusive economic growth at $15 \%$ and $10 \%$ significance levels. During the period 1996-2016 natural resource rents positively affect inclusive economic growth with a statistical significance.

\subsubsection{Reduced Form Model Estimations}

We build reduced form models with only the variables that show statistically significant effects on inclusive economic growth rate in the benchmark estimations for both the before and after Global Financial Crisis periods as another level of robustness check. Table 4 in the appendix presents these reduced form models estimation results. Although the impacts of some indicators now lose their statistical significance the direction of their influences comply with the results in tables 1 and 2 . Consistent with previous outcomes, investment, lagged GDP, secondary education, high technology exports, and tertiary education exert statistically significant impacts on inclusive growth. 
Table 1. Inclusive Growth Before the Global Financial Crisis, 1996-2007

\begin{tabular}{|c|c|c|c|c|c|c|c|c|c|c|}
\hline & (1) & (2) & (3) & (4) & (5) & (6) & (7) & (8) & (9) & (10) \\
\hline investment & $\begin{array}{l}0.00116 \\
(0.0014)\end{array}$ & $\begin{array}{c}0.00547 * * * \\
(0.00188)\end{array}$ & $\begin{array}{c}0.00112 \\
(0.00147)\end{array}$ & $\begin{array}{c}0.00134 \\
(0.00137)\end{array}$ & $\begin{array}{c}0.00128 \\
(0.00153)\end{array}$ & $\begin{array}{c}0.00106 \\
(0.00168)\end{array}$ & $\begin{array}{c}0.00149 \\
(0.00146)\end{array}$ & $\begin{array}{c}0.00102 \\
(0.00148)\end{array}$ & $\begin{array}{c}0.00126 \\
(0.00137)\end{array}$ & $\begin{array}{c}0.00179 \\
(0.00212)\end{array}$ \\
\hline h-consumption & $\begin{array}{c}0.00214 \\
(0.00164)\end{array}$ & $\begin{array}{l}-0.00207 \\
(0.00186)\end{array}$ & $\begin{array}{c}0.00234 \\
(0.00178)\end{array}$ & $\begin{array}{c}0.00223 \\
(0.00157)\end{array}$ & $\begin{array}{c}0.00202 \\
(0.00167)\end{array}$ & $\begin{array}{c}0.00213 \\
(0.00165)\end{array}$ & $\begin{array}{c}0.0021 \\
(0.0016)\end{array}$ & $\begin{array}{c}0.00204 \\
(0.00174)\end{array}$ & $\begin{array}{c}0.00219 \\
(0.00172)\end{array}$ & $\begin{array}{c}0.0021 \\
(0.00181)\end{array}$ \\
\hline $\mathrm{CO}_{2}$ emissions & $\begin{array}{r}-0.139 \\
(0.152)\end{array}$ & $\begin{array}{l}-0.354^{*} \\
(0.205)\end{array}$ & $\begin{array}{l}-0.142 \\
(0.151)\end{array}$ & $\begin{array}{l}-0.115 \\
(0.139)\end{array}$ & $\begin{array}{c}-0.144 \\
(0.152)\end{array}$ & $\begin{array}{c}-0.140 \\
(0.153)\end{array}$ & $\begin{array}{c}-0.144 \\
(0.148)\end{array}$ & $\begin{array}{l}-0.131 \\
(0.151)\end{array}$ & $\begin{array}{l}-0.138 \\
(0.151)\end{array}$ & $\begin{array}{l}-0.119 \\
(0.131)\end{array}$ \\
\hline fdi & $\begin{array}{l}-0.00221 \\
(0.0015)\end{array}$ & $\begin{array}{l}-0.00106 \\
(0.00137)\end{array}$ & $\begin{array}{l}-0.00233 * \\
(0.00148)\end{array}$ & $\begin{array}{l}-0.00251^{*} \\
(0.00159)\end{array}$ & $\begin{array}{l}-0.00208 \\
(0.0014)\end{array}$ & $\begin{array}{l}-0.00224 \\
(0.00152)\end{array}$ & $\begin{array}{r}-0.00231 \\
(0.00155)\end{array}$ & $\begin{array}{l}-0.00211 \\
(0.00146)\end{array}$ & $\begin{array}{c}-0.00228^{*} \\
(0.00148)\end{array}$ & $\begin{array}{c}-0.00241^{*} \\
(0.00149)\end{array}$ \\
\hline lagged gdp & $\begin{array}{c}-0.426 * * * * \\
(0.101)\end{array}$ & $\begin{array}{l}-.639 * * * * \\
(0.110)\end{array}$ & $\begin{array}{l}-.448 * * * * \\
(0.109)\end{array}$ & $\begin{array}{l}-.44 * * * * \\
(0.103)\end{array}$ & $\begin{array}{l}-.427 * * * * \\
(0.103)\end{array}$ & $\begin{array}{l}-.428 * * * * \\
(0.100)\end{array}$ & $\begin{array}{l}-.423 * * * * \\
(0.103)\end{array}$ & $\begin{array}{c}-0.431 * * * * \\
(0.101)\end{array}$ & $\begin{array}{c}-0.427 * * * * \\
(0.103)\end{array}$ & $\begin{array}{c}-0.464 * * * * \\
(0.118)\end{array}$ \\
\hline govt. expenditure & $\begin{array}{c}-0.00563^{* *} \\
(0.00311)\end{array}$ & $\begin{array}{c}0.00288 \\
(0.00358)\end{array}$ & $\begin{array}{c}-0.00579 * * \\
(0.00307)\end{array}$ & $\begin{array}{l}-0.00665 * * \\
(0.00334)\end{array}$ & $\begin{array}{r}-0.00485 \\
(0.00349)\end{array}$ & $\begin{array}{l}-0.0056 * * \\
(0.00309)\end{array}$ & $\begin{array}{c}-0.00564 * * \\
(0.00321)\end{array}$ & $\begin{array}{c}-0.00593 * * \\
(0.00336)\end{array}$ & $\begin{array}{c}-0.00575^{* *} \\
(0.00311)\end{array}$ & $\begin{array}{l}-0.00628^{*} \\
(0.00394)\end{array}$ \\
\hline inflation & $\begin{array}{c}-0.000995 * * \\
(0.000494)\end{array}$ & $\begin{array}{l}-0.000265 \\
(0.000637)\end{array}$ & $\begin{array}{l}-0.00132 * * \\
(0.000625)\end{array}$ & $\begin{array}{l}-.0013 * * * * \\
(0.000403)\end{array}$ & $\begin{array}{l}-0.000805 \\
(0.000575)\end{array}$ & $\begin{array}{c}-0.000986^{* *} \\
(0.000520)\end{array}$ & $\begin{array}{l}-.00116^{* * * *} \\
(0.000541)\end{array}$ & $\begin{array}{l}-.000896^{*} \\
(0.000514)\end{array}$ & $\begin{array}{c}-0.00109 * * * * \\
(0.000507)\end{array}$ & $\begin{array}{l}-.00146 * * * \\
(0.000672)\end{array}$ \\
\hline trade & $\begin{array}{l}0.00137 * * \\
(0.000749)\end{array}$ & $\begin{array}{c}0.00101 \\
(0.000799)\end{array}$ & $\begin{array}{l}0.00146 * * \\
(0.000757)\end{array}$ & $\begin{array}{c}0.00117 \\
(0.00084)\end{array}$ & $\begin{array}{c}0.00136^{*} \\
(0.000774)\end{array}$ & $\begin{array}{l}0.00138 * * \\
(0.000772)\end{array}$ & $\begin{array}{l}0.00143 * * \\
(0.000721)\end{array}$ & $\begin{array}{l}0.00137 * * \\
(0.000766)\end{array}$ & $\begin{array}{c}0.00136 * * \\
(0.00076)\end{array}$ & $\begin{array}{c}0.00131 \\
(0.000878)\end{array}$ \\
\hline secondary education & $\begin{array}{c}0.00236 * * \\
(0.00118)\end{array}$ & $\begin{array}{l}0.0025 * * * \\
(0.000918)\end{array}$ & $\begin{array}{c}0.00232 * * \\
(0.0011)\end{array}$ & $\begin{array}{c}0.00262 * * \\
(0.00129)\end{array}$ & $\begin{array}{c}0.0021^{*} \\
(0.00124)\end{array}$ & $\begin{array}{c}0.0024 * * \\
(0.0013)\end{array}$ & $\begin{array}{c}0.00262 * * * \\
(0.0012)\end{array}$ & $\begin{array}{c}0.00233 * * \\
(0.00116)\end{array}$ & $\begin{array}{c}0.00241 * * \\
(0.00122)\end{array}$ & $\begin{array}{l}0.0025 * * \\
(0.00141)\end{array}$ \\
\hline unemployment & $\begin{array}{l}-0.00208 \\
(0.00305)\end{array}$ & $\begin{array}{c}-0.00212 \\
(0.00416)\end{array}$ & $\begin{array}{l}-0.00272 \\
(0.00321)\end{array}$ & $\begin{array}{l}-0.00287 \\
(0.00263)\end{array}$ & $\begin{array}{l}-0.00196 \\
(0.00348)\end{array}$ & $\begin{array}{l}-0.00206 \\
(0.00313)\end{array}$ & $\begin{array}{l}-0.00226 \\
(0.00301)\end{array}$ & $\begin{array}{l}-0.00187 \\
(0.00323)\end{array}$ & $\begin{array}{l}-0.00229 \\
(0.00312)\end{array}$ & $\begin{array}{c}-0.00333 \\
(0.00342)\end{array}$ \\
\hline life expectancy & $\begin{array}{c}0.0106^{*} \\
(0.00628)\end{array}$ & $\begin{array}{c}0.00407 \\
(0.00913)\end{array}$ & $\begin{array}{c}0.00884 \\
(0.00591)\end{array}$ & $\begin{array}{c}0.00784 \\
(0.00656)\end{array}$ & $\begin{array}{l}0.0115 * * \\
(0.00629)\end{array}$ & $\begin{array}{c}0.0108^{*} \\
(0.00623)\end{array}$ & $\begin{array}{c}0.00714 \\
(0.00636)\end{array}$ & $\begin{array}{l}0.0119 * * \\
(0.00672)\end{array}$ & $\begin{array}{c}0.00958 * * \\
(0.00534)\end{array}$ & $\begin{array}{c}0.00403 \\
(0.00781)\end{array}$ \\
\hline domestic credit & $\begin{array}{c}0.002 * \\
(0.00131)\end{array}$ & $\begin{array}{c}0.00134 \\
(0.00124)\end{array}$ & $\begin{array}{l}0.00204 * \\
(0.00128)\end{array}$ & $\begin{array}{l}0.00218^{*} \\
(0.00135)\end{array}$ & $\begin{array}{c}0.00182 \\
(0.00137)\end{array}$ & $\begin{array}{l}0.00205^{*} \\
(0.00128)\end{array}$ & $\begin{array}{c}0.00203 \\
(0.00135)\end{array}$ & $\begin{array}{l}0.00191 \\
(0.0013)\end{array}$ & $\begin{array}{l}0.00203 * \\
(0.00133)\end{array}$ & $\begin{array}{c}0.00182 \\
(0.00134)\end{array}$ \\
\hline high-tech exports & $\begin{array}{l}0.00215^{*} \\
(0.00141)\end{array}$ & $\begin{array}{c}0.00223 * * \\
(0.00108)\end{array}$ & $\begin{array}{l}0.00196^{*} \\
(0.0134)\end{array}$ & $\begin{array}{c}0.00224 \\
(0.00152)\end{array}$ & $\begin{array}{l}0.00225^{*} \\
(0.00133)\end{array}$ & $\begin{array}{l}0.00207 * \\
(0.00124)\end{array}$ & $\begin{array}{l}0.00241 * * \\
(0.00136)\end{array}$ & $\begin{array}{c}0.00207 \\
(0.00142)\end{array}$ & $\begin{array}{c}0.0022 * \\
(0.00143)\end{array}$ & $\begin{array}{c}0.0025 * * * \\
(0.00111)\end{array}$ \\
\hline tertiary education & & $\begin{array}{c}0.00599 * * * * \\
(0.00140)\end{array}$ & & & & & & & & \\
\hline voice\&accountability & & & -0.0255 & & & & & & & -0.0290 \\
\hline
\end{tabular}


$(0.0346)$

political stability

govt. effectiveness

regulatory quality

rule of law

corruption control

wgi average

0.00769

$-0.0103$

(0.0433)

$$
-0.0260
$$

$-0.0364$

\begin{tabular}{|c|c|c|c|c|c|c|c|c|c|c|}
\hline constant & $\begin{array}{c}2.947 * * * * \\
(0.936)\end{array}$ & $\begin{array}{c}5.308 * * * * \\
(1.349)\end{array}$ & $\begin{array}{c}3.267 * * * * \\
(1.055)\end{array}$ & $\begin{array}{c}3.243 * * * * \\
(0.971)\end{array}$ & $\begin{array}{c}2.911 * * * * \\
(0.992)\end{array}$ & $\begin{array}{c}2.954 * * * * \\
(0.945)\end{array}$ & $\begin{array}{c}3.141 * * * * \\
(1.040)\end{array}$ & $\begin{array}{c}2.921 * * * * \\
(0.932)\end{array}$ & $\begin{array}{c}3.028 * * * * \\
(0.965)\end{array}$ & $\begin{array}{c}3.77 * * * * \\
(1.258)\end{array}$ \\
\hline Observations & 119 & 101 & 119 & 119 & 119 & 119 & 119 & 119 & 119 & 119 \\
\hline $\mathrm{R}$-squared & 0.403 & 0.530 & 0.409 & 0.410 & 0.414 & 0.404 & 0.408 & 0.405 & 0.404 & 0.439 \\
\hline
\end{tabular}

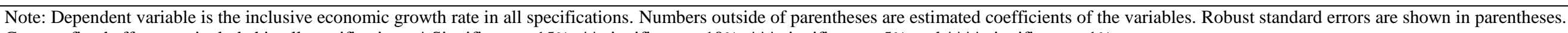
Country fixed effects are included in all specifications. * Significant at 15\%; ** significant at $10 \%$; *** significant at $5 \%$ and $* * * *$ significant at $1 \%$. 
Table 2. Inclusive Growth After the Global Financial Crisis, 2008-2016

\begin{tabular}{|c|c|c|c|c|c|c|c|c|c|c|}
\hline 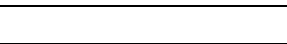 & (1) & (2) & (3) & (4) & (5) & (6) & (7) & (8) & (9) & (10) \\
\hline investment & $\begin{array}{c}0.00172 \\
(0.00215)\end{array}$ & $\begin{array}{c}0.00143 \\
(0.00234)\end{array}$ & $\begin{array}{c}0.00227 \\
(0.00199)\end{array}$ & $\begin{array}{l}0.00194 \\
(0.0021)\end{array}$ & $\begin{array}{c}0.00153 \\
(0.00211)\end{array}$ & $\begin{array}{c}0.00147 \\
(0.00217)\end{array}$ & $\begin{array}{l}0.00156 \\
(0.0022)\end{array}$ & $\begin{array}{c}0.00169 \\
(0.00214)\end{array}$ & $\begin{array}{c}0.00142 \\
(0.00206)\end{array}$ & $\begin{array}{c}0.00316 \\
(0.00219)\end{array}$ \\
\hline h-consumption & $\begin{array}{l}-0.0017 \\
(0.0016)\end{array}$ & $\begin{array}{l}-0.00194 \\
(0.00226)\end{array}$ & $\begin{array}{l}-0.00215 \\
(0.00154)\end{array}$ & $\begin{array}{l}-0.00192 \\
(0.00154)\end{array}$ & $\begin{array}{c}-0.0013 \\
(0.00128)\end{array}$ & $\begin{array}{l}-0.00136 \\
(0.00140)\end{array}$ & $\begin{array}{l}-0.00127 \\
(0.00148)\end{array}$ & $\begin{array}{l}-0.00173 \\
(0.00173)\end{array}$ & $\begin{array}{l}-0.00134 \\
(0.00154)\end{array}$ & $\begin{array}{l}-0.00161 \\
(0.00121)\end{array}$ \\
\hline $\mathrm{CO}_{2}$ emissions & $\begin{array}{l}-0.408 \\
(0.280)\end{array}$ & $\begin{array}{r}-0.147 \\
(0.219)\end{array}$ & $\begin{array}{r}-0.447 \\
(0.297)\end{array}$ & $\begin{array}{l}-0.408 \\
(0.290)\end{array}$ & $\begin{array}{l}-0.404 * \\
(0.259)\end{array}$ & $\begin{array}{c}-0.396 \\
(0.262)\end{array}$ & $\begin{array}{l}-0.455^{*} \\
(0.277)\end{array}$ & $\begin{array}{l}-0.405 \\
(0.281)\end{array}$ & $\begin{array}{l}-0.421^{*} \\
(0.269)\end{array}$ & $\begin{array}{c}-0.563 * * \\
(0.278)\end{array}$ \\
\hline fdi & $\begin{array}{l}0.00272 \\
(0.0049)\end{array}$ & $\begin{array}{c}0.00307 \\
(0.00267)\end{array}$ & $\begin{array}{c}0.00201 \\
(0.00449)\end{array}$ & $\begin{array}{r}0.00261 \\
(0.00497)\end{array}$ & $\begin{array}{r}0.00353 \\
(0.00467)\end{array}$ & $\begin{array}{c}0.00271 \\
(0.005)\end{array}$ & $\begin{array}{c}0.00307 \\
(0.0045)\end{array}$ & $\begin{array}{l}0.00269 \\
(0.0048)\end{array}$ & $\begin{array}{c}0.00285 \\
(0.00452)\end{array}$ & $\begin{array}{c}0.00376 \\
(0.00402)\end{array}$ \\
\hline lagged gdp & $\begin{array}{c}-0.469 * * * * \\
(0.0623)\end{array}$ & $\begin{array}{l}-.617 * * * * \\
(0.181)\end{array}$ & $\begin{array}{l}-.490 * * * * \\
(0.0555)\end{array}$ & $\begin{array}{l}-.47 * * * * \\
(0.0617)\end{array}$ & $\begin{array}{l}-.465 * * * * \\
(0.067)\end{array}$ & $\begin{array}{l}-.469 * * * * \\
(0.0655)\end{array}$ & $\begin{array}{l}-.478 * * * * \\
(0.0682)\end{array}$ & $\begin{array}{c}-0.471 * * * * \\
(0.0637)\end{array}$ & $\begin{array}{c}-0.484 * * * * \\
(0.0651)\end{array}$ & $\begin{array}{c}-0.475 * * * * \\
(0.0853)\end{array}$ \\
\hline govt. expenditure & $\begin{array}{l}-0.00351 \\
(0.00379)\end{array}$ & $\begin{array}{l}-0.00532 \\
(0.00445)\end{array}$ & $\begin{array}{l}-0.00403 \\
(0.00368)\end{array}$ & $\begin{array}{r}-0.00343 \\
(0.00388)\end{array}$ & $\begin{array}{r}-0.00415 \\
(0.00426)\end{array}$ & $\begin{array}{c}-0.0031 \\
(0.00366)\end{array}$ & $\begin{array}{l}-0.00436 \\
(0.00394)\end{array}$ & $\begin{array}{l}-0.00369 \\
(0.00385)\end{array}$ & $\begin{array}{l}-0.00439 \\
(0.0038)\end{array}$ & $\begin{array}{l}-0.00468 \\
(0.00412)\end{array}$ \\
\hline inflation & $\begin{array}{l}-0.00125 \\
(0.00335)\end{array}$ & $\begin{array}{c}-0.005 \\
(0.00349)\end{array}$ & $\begin{array}{r}-0.00101 \\
(0.0034)\end{array}$ & $\begin{array}{r}-0.00116 \\
(0.00337)\end{array}$ & $\begin{array}{l}-0.00159 \\
(0.00354)\end{array}$ & $\begin{array}{l}-0.00136 \\
(0.00329)\end{array}$ & $\begin{array}{l}-0.00129 \\
(0.00319)\end{array}$ & $\begin{array}{l}-0.00123 \\
(0.00338)\end{array}$ & $\begin{array}{l}-0.00139 \\
(0.00331)\end{array}$ & $\begin{array}{l}-0.00142 \\
(0.00316)\end{array}$ \\
\hline trade & $\begin{array}{l}0.0000441 \\
(0.000385)\end{array}$ & $\begin{array}{c}0.002 * * \\
(0.000944)\end{array}$ & $\begin{array}{c}0.000205 \\
(0.000417)\end{array}$ & $\begin{array}{l}-0.0000921 \\
(0.000452)\end{array}$ & $\begin{array}{l}-0.0000445 \\
(0.000409)\end{array}$ & $\begin{array}{l}0.0000456 \\
(0.000374)\end{array}$ & $\begin{array}{c}0.000118 \\
(0.000387)\end{array}$ & $\begin{array}{l}0.0000383 \\
(0.000413)\end{array}$ & $\begin{array}{c}0.000212 \\
(0.000391)\end{array}$ & $\begin{array}{l}-0.000126 \\
(0.000496)\end{array}$ \\
\hline secondary education & $\begin{array}{c}0.00379 * * * * \\
(0.000964)\end{array}$ & $\begin{array}{c}0.00231 * * \\
(0.00127)\end{array}$ & $\begin{array}{r}0.0042 * * * * \\
(0.000894)\end{array}$ & $\begin{array}{c}0.00379 * * * * \\
(0.000968)\end{array}$ & $\begin{array}{c}0.00355 * * * * \\
(0.000956)\end{array}$ & $\begin{array}{c}0.00374 * * * * \\
(0.000984)\end{array}$ & $\begin{array}{c}0.0037 * * * * \\
(0.000963)\end{array}$ & $\begin{array}{c}0.00377 * * * * \\
(0.00097)\end{array}$ & $\begin{array}{c}0.00379 * * * * \\
(0.000929)\end{array}$ & $\begin{array}{c}0.00408 * * * * \\
(0.000676)\end{array}$ \\
\hline unemployment & $\begin{array}{l}-0.00648 \\
(0.00452)\end{array}$ & $\begin{array}{l}-0.00511 \\
(0.00516)\end{array}$ & $\begin{array}{c}-0.00886 * * \\
(0.00436)\end{array}$ & $\begin{array}{c}-0.00772 * * \\
(0.004)\end{array}$ & $\begin{array}{l}-0.00432 \\
(0.00715)\end{array}$ & $\begin{array}{l}-0.00541 \\
(0.00646)\end{array}$ & $\begin{array}{l}-0.00315 \\
(0.00727)\end{array}$ & $\begin{array}{l}-0.00647 \\
(0.00463)\end{array}$ & $\begin{array}{c}-0.0043 \\
(0.00612)\end{array}$ & $\begin{array}{l}-0.00619 \\
(0.00638)\end{array}$ \\
\hline life expectancy & $\begin{array}{l}0.00896 \\
(0.0114)\end{array}$ & $\begin{array}{l}0.0430 * \\
(0.0255)\end{array}$ & $\begin{array}{l}0.00553 \\
(0.0106)\end{array}$ & $\begin{array}{c}0.00532 \\
(0.00949)\end{array}$ & $\begin{array}{c}0.0191 \\
(0.0144)\end{array}$ & $\begin{array}{c}0.0129 \\
(0.00974)\end{array}$ & $\begin{array}{c}0.0212 \\
(0.0143)\end{array}$ & $\begin{array}{l}0.0099 \\
(0.014)\end{array}$ & $\begin{array}{c}0.0213 \\
(0.0149)\end{array}$ & $\begin{array}{l}0.0141 \\
(0.018)\end{array}$ \\
\hline domestic credit & $\begin{array}{l}0.000237 \\
(0.00109)\end{array}$ & $\begin{array}{c}-0.00112 \\
(0.000771)\end{array}$ & $\begin{array}{l}-0.000146 \\
(0.000993)\end{array}$ & $\begin{array}{c}0.000204 \\
(0.0011)\end{array}$ & $\begin{array}{c}-0.0000102 \\
(0.00119)\end{array}$ & $\begin{array}{l}0.000114 \\
(0.00114)\end{array}$ & $\begin{array}{l}0.000159 \\
(0.00107)\end{array}$ & $\begin{array}{l}0.000222 \\
(0.00108)\end{array}$ & $\begin{array}{c}-0.0000916 \\
(0.00104)\end{array}$ & $\begin{array}{l}-0.000687 \\
(0.00097)\end{array}$ \\
\hline high-tech exports & $\begin{array}{c}0.00439 * * * \\
(0.00185)\end{array}$ & $\begin{array}{c}0.00636 * * * \\
(0.00266)\end{array}$ & $\begin{array}{c}0.00331 * * * \\
(0.00152)\end{array}$ & $\begin{array}{c}0.00417 * * * \\
(0.00182)\end{array}$ & $\begin{array}{l}0.00435 * * \\
(0.00208)\end{array}$ & $\begin{array}{c}0.00425^{* *} \\
(0.00219)\end{array}$ & $\begin{array}{c}0.00418^{* * *} \\
(0.00194)\end{array}$ & $\begin{array}{c}0.00434 * * * \\
(0.00193)\end{array}$ & $\begin{array}{c}0.00389 * * \\
(0.00192)\end{array}$ & $\begin{array}{c}0.00255 \\
(0.00201)\end{array}$ \\
\hline tertiary education & & $\begin{array}{l}0.00191 * * \\
(0.000958)\end{array}$ & & & & & & & & \\
\hline voice\&accountability & & & $0.0349 * *$ & & & & & & & $0.0505 * * *$ \\
\hline
\end{tabular}


$(0.0166)$

political stability

govt. effectiveness

regulatory quality

rule of law

corruption control

wgi average

constant

$3.887 * * * * \quad 2.637 * * \quad 4.414 * * * *$

Observations

$\begin{array}{cc}(1.472) & (0.975) \\ 55 & 68 \\ 0.680 & 0.599\end{array}$

$-0.0147$

(0.0266)

0.0423
$(0.0779)$

(0.0226)

$-0.0442$

(0.0323)

0.0774

(0.0943)

0.0267

(0.0679)

$-0.0246$

(0.0569)

0.0695

0.0972

(0.0625)

(0.08)

0.00558

$(0.0455)$

$-0.0662$

(0.0451)

0.0832

(0.0692)

R-squared

$4.180 * * * *$

$3.095 * * *$

$3.577 * * * *$

68

0.580

(1.091)

68
0.584

$(0.901)$
68
0.579

$3.042 * * *$

0.579

$(1.16)$
68
0.597

68
0.597

$3.85 * * * *$

(1.152)

$3.126 * * *$

0.577

(1.206)

$3.625 * * * *$ (0.989)

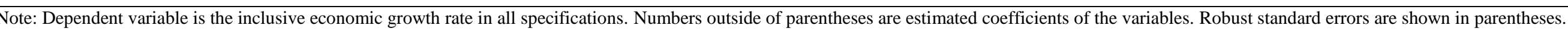
Country fixed effects are included in all specifications. * Significant at 15\%; ** significant at 10\%; *** significant at 5\% and **** significant at $1 \%$. 


\section{Conclusive Remarks}

We investigate the factors which affect inclusive growth in 16 MENA region countries before and after the Global Financial Crisis with panel data estimations using one-way fixed effects model. In order to measure inclusive economic growth, we form a statistic by integrating GDP per capita growth rate and Gini coefficient change rate.

The before Global Financial Crisis period covers the 19962007 time period. Before the Global Financial Crisis, a higher investment level, trade volume, secondary and tertiary education levels, high technology goods exports positively affect inclusive economic growth. On the other hand, environmental quality deterioration, macroeconomic volatility which is measured by an increasing inflation rate and a lack of fiscal discipline are found to be negatively influencing inclusive economic growth with a statistical significance.

The after Global Financial Crisis period refers to the 20082016 time period. We find out that after the start of Global Financial Crisis lower $\mathrm{CO}_{2}$ emissions, higher trade volume, higher education level, lower unemployment, higher life expectancy, and higher technology developments positively impact inclusive economic growth. Moreover, it is found that after the Global Financial Crisis improvements in voice and accountability increased inclusive growth rates.

Both before and after the Global Financial Crisis lagged GDP per capita which measures conditional convergence appears to be negatively correlated with inclusive growth, and the correlation is statistically significant at $1 \%$ level. Hence, if a country has fallen behind in economic growth compared to other countries in the past this positively affects economic inclusiveness within that country. The estimation results in robustness check section turn out to be generally consistent with the benchmark models estimation results.

Policy makers should design and implement policies conducive to environmental protection, macroeconomic stability, fiscal discipline, open trade, higher educational attainment, social development, and greater export volume of technology intensive goods in order to achieve higher inclusive growth in the national economy and higher wellbeing of the society within the 16 MENA countries. Furthermore, for the same goal, they should improve free elections process, accountability, regulatory institutions' functioning, and effectiveness of the government units. Future research may focus on inclusive institutions, and relationships between gender issues and inclusive growth.

\section{References}

Abdu, M., Buba, A., \& Kareem Alhassan, A. (2018). Macroeconomic Stability and Inclusive Growth in Nigeria: A Cointegration Approach. Pakistan Journal of Humanities and Social Sciences, 6(3), 370-389.

Agarwal, H. (2012). Recent Trends in Export Led Growth in India: An Empirical Reinvestigation of Constraints and
Possible Solutions for Inclusive Economic Development. International Journal of Management Research and Reviews, 2(10), 1864-1874.

Ali, I., \& Son, H. H. (2007). Measuring inclusive growth. Asian Development Review, 24(1), 11-31.

Alvaredo, F., Assouad, L., \& Piketty, T. (2019). Measuring Inequality in the Middle East 1990-2016: The World's Most Unequal Region?. Review of Income and Wealth, 65(4), 685-711.

Anand, R., Mishra, M. S., \& Peiris, S. J. (2013). Inclusive growth: Measurement and determinants (No. 13-135). International Monetary Fund, 1-27.

Aoyagi, C., \& Ganelli, G. (2015). Asia's quest for inclusive growth revisited. Journal of Asian Economics, 40, 29-46.

Arabiyat, T. S., Mdanat, M., \& Samawi, G. (2020). Trade openness, inclusive growth, and inequality: evidence from Jordan. The Journal of Developing Areas, 54(1).

Arezki, M. R., \& Nabli, M. M. K. (2012). Natural resources, volatility, and inclusive growth: perspectives from the Middle East and North Africa. International Monetary Fund, 1-33.

Asongu, S. A., \& Odhiambo, N. M. (2020). Governance, CO2 emissions and inclusive human development in subSaharan Africa. Energy Exploration \& Exploitation, 38(1), 18-36.

Boarini, R., F. Murtin and P. Schreyer (2015), "Inclusive Growth: The OECD Measurement Framework", OECD Statistics Working Papers, No. 2015/06, OECD Publishing, Paris, https://doi.org/10.1787/5jrqppxjqhg4en.

Canlas, D. B. (2016). Investing in human capital for inclusive growth: focus on higher education (No. 2016-02). PIDS Discussion Paper Series, 1-17.

Cherkaoui, M., Abdelkhalek, T., Angeli, A., Bibi, S., David, S., Douidich, M., ... \& MA, M. (2009, September). Growth, inequality, and poverty alleviation policies in the MENA region. In XXVI International Population Conference, Marrakesh, September-October.

Dinda, S. (2014). Inclusive growth through creation of human and social capital. International Journal of Social Economics, 878-895.

Gyamfi, N.-M., Bokpin, G. A., Aboagye, A. Q. Q., \& Ackah, C. G. (2019). Financial Development, Institutional Quality and Inclusive Growth in Africa. Global Business Review, https://doi.org/10.1177/0972150919875367.

Hakimian, H., Said, M., Karshenas, M., \& Alami, R. (2014). Inclusive growth in MENA: employment and poverty dimensions in a comparative context, 1-157.

Ianchovichina, E., \& Lundstrom, S. (2009). Inclusive growth analytics: Framework and application. The World Bank, $1-40$. 
Islam, R. (2014, June). Human capital and inclusive growth: The challenges for Bangladesh. In First BEF Conference on Vision (Vol. 2030), 1-36.

Jones, C. I., \& Klenow, P. J. (2016). Beyond GDP? Welfare across countries and time. American Economic Review, 106(9), 2426-2457.

Kumah, F. Y., \& Sandy, M. (2013). In search of inclusive growth: The role of economic institutions and policy. Modern Economy, Vol. 4, No. 11, 758-775.

Nabi, M. S. (2013). Role of Islamic finance in promoting inclusive economic development. In Global Sustainable Finance Conference, 1-39.

Ncube, M., Anyanwu, J. C., \& Hausken, K. (2014). Inequality, economic growth and poverty in the Middle East and North Africa (MENA). African Development Review, 26(3), 435-453.

NGUYEN, L. P., \& PHAM, V. H. T. (2020). Trade of ICT products, government, and economic growth: Evidence from East Asia-Pacific region. The Journal of Asian Finance, Economics, and Business, 7(8), 175-183.

Okafor, S. O., Jegbefumwen, K., \& Ike, A. N. (2016). Human capital investment for inclusive and sustainable economic development: The Nigerian experience. British Journal of Economics, Finance and Management Sciences, 11(1), 107-121.

Oluwadamilola, O., Akinyemi, O., \& Adediran, O. (2018). Human capital development and inclusive growth: Implications for achieving SDG-4 in Nigeria. African Population Studies, 32(1), 4088-4096.

O’Sullivan, A., Rey, M. E., \& Mendez, J. G. (2011). Opportunities and Challenges in the MENA Region. Arab world competitiveness report, 2012, 42-67.

Ranieri, R., \& Almeida Ramos, R. (2013). Inclusive growth: Building up a concept (No. 104). Working Paper, 1-26.
Rodrik, D. (2014). The past, present, and future of economic growth. Challenge, 57(3), 5-39.

Roser, M. \& Thewissen, S. (2017). The US lags far behind its peers on "inclusive" economic growth. https://www.vox.com/the-bigidea/2017/2/3/14491964/growth-inequality-comparativeus-europe.

Stiglitz, J. E. (2012). The price of inequality: How today's divided society endangers our future. WW Norton \& Company.

Taskin, T. (2014). GDP Growth in Turkey: Inclusive or not. Central Bank Review, 14(2), 31-64.

Thewissen, S., Kenworthy, L., Nolan, B., Roser, M., \& Smeeding, T. (2015). Rising income inequality and living standards in OECD countries: How does the middle fare? (No. 656). LIS Working Paper Series, 1-30.

Thorat, S., \& Dubey, A. (2012). Has growth been socially inclusive during 1993-94-2009-10?. Economic and Political Weekly, 43-53.

Vellala, P. S., Madala, M. K., \& Chhattopadhyay, U. (2014). A theoretical model for inclusive economic growth in Indian context. International Journal of Humanities and Social Science, 4(13), 229-235.

World Bank (2009). What is Inclusive Growth? Washington DC: World Bank.

Yinusa, O. G., Aworinde, O. B., \& Odusanya, I. A. (2020). Institutional quality, financial development and inclusive growth: Asymmetric cointegration approach.

International Journal of Management, Economics and Social Sciences (IJMESS), 9(3), 182-205.

Zulfiqar, K. (2018). Fiscal Policy for Inclusive Growth: A Case Study of Pakistan. Pakistan Economic and Social Review, 56(1), 21-24. 


\section{Appendix}

Table 3. Inclusive Growth, 1996-2016

\begin{tabular}{|c|c|c|c|c|c|c|c|c|c|c|}
\hline & $(1)$ & (2) & (3) & (4) & $(5)$ & (6) & $(7)$ & (8) & $(9)$ & $(10)$ \\
\hline investment & $\begin{array}{l}0.000669 \\
(0.00235)\end{array}$ & $\begin{array}{c}0.00146 \\
(0.00223)\end{array}$ & $\begin{array}{l}0.000663 \\
(0.00233)\end{array}$ & $\begin{array}{l}0.000846 \\
(0.00237)\end{array}$ & $\begin{array}{c}0.00111 \\
(0.00203)\end{array}$ & $\begin{array}{c}0.00136 \\
(0.00162)\end{array}$ & $\begin{array}{c}0.00066 \\
(0.00228)\end{array}$ & $\begin{array}{l}0.000341 \\
(0.00236)\end{array}$ & $\begin{array}{c}0.000504 \\
(0.0023)\end{array}$ & $\begin{array}{c}0.00159 \\
(0.00141)\end{array}$ \\
\hline h-consumption & $\begin{array}{c}0.000606 \\
(0.000891)\end{array}$ & $\begin{array}{l}0.0000676 \\
(0.00104)\end{array}$ & $\begin{array}{c}0.000592 \\
(0.000937)\end{array}$ & $\begin{array}{c}0.000557 \\
(0.000898)\end{array}$ & $\begin{array}{c}0.00129 \\
(0.000928)\end{array}$ & $\begin{array}{c}0.00119 \\
(0.00109)\end{array}$ & $\begin{array}{c}0.000666 \\
(0.000849)\end{array}$ & $\begin{array}{c}0.000314 \\
(0.000798)\end{array}$ & $\begin{array}{l}0.000586 \\
(0.00081)\end{array}$ & $\begin{array}{c}0.00126 \\
(0.00101)\end{array}$ \\
\hline $\mathrm{CO}_{2}$ emissions & $\begin{array}{l}-0.191 \\
(0.129)\end{array}$ & $\begin{array}{l}-0.234 * * \\
(0.109)\end{array}$ & $\begin{array}{c}-0.192 \\
(0.130)\end{array}$ & $\begin{array}{r}-0.185 \\
(0.123)\end{array}$ & $\begin{array}{r}-0.149 \\
(0.139)\end{array}$ & $\begin{array}{c}-0.143 \\
(0.148)\end{array}$ & $\begin{array}{l}-0.202^{*} \\
(0.121)\end{array}$ & $\begin{array}{l}-0.141 \\
(0.13)\end{array}$ & $\begin{array}{l}-0.161 \\
(0.143)\end{array}$ & $\begin{array}{l}-0.116 \\
(0.12)\end{array}$ \\
\hline fdi & $\begin{array}{c}0.00179 \\
(0.00196)\end{array}$ & $\begin{array}{c}0.00226 \\
(0.00179)\end{array}$ & $\begin{array}{c}0.0018 \\
(0.00195)\end{array}$ & $\begin{array}{c}0.0018 \\
(0.00192)\end{array}$ & $\begin{array}{r}0.00103 \\
(0.00149)\end{array}$ & $\begin{array}{c}0.00047 \\
(0.00124)\end{array}$ & $\begin{array}{r}0.00186 \\
(0.00199)\end{array}$ & $\begin{array}{c}0.00177 \\
(0.00191)\end{array}$ & $\begin{array}{c}0.0015 \\
(0.00176)\end{array}$ & $\begin{array}{l}0.000482 \\
(0.00106)\end{array}$ \\
\hline lagged gdp & $\begin{array}{c}-0.197 * * * * * \\
(0.0404)\end{array}$ & $\begin{array}{l}-0.28 * * * * \\
(0.067)\end{array}$ & $\begin{array}{l}-0.198 * * * * \\
(0.0401)\end{array}$ & $\begin{array}{l}-0.2 * * * * \\
(0.0443)\end{array}$ & $\begin{array}{l}-0.18 * * * * \\
(0.0377)\end{array}$ & $\begin{array}{l}-0.221 * * * * \\
(0.0545)\end{array}$ & $\begin{array}{l}-0.2 * * * * \\
(0.0407)\end{array}$ & $\begin{array}{c}-0.212 * * * * \\
(0.044)\end{array}$ & $\begin{array}{c}-0.204 * * * * \\
(0.041)\end{array}$ & $\begin{array}{c}-0.234 * * * * \\
(0.063)\end{array}$ \\
\hline govt. expenditure & $\begin{array}{l}-0.00112 \\
(0.00119)\end{array}$ & $\begin{array}{l}-0.000691 \\
(0.00226)\end{array}$ & $\begin{array}{l}-0.00112 \\
(0.00119)\end{array}$ & $\begin{array}{r}-0.00141 \\
(0.00129)\end{array}$ & $\begin{array}{r}-0.00153 \\
(0.00143)\end{array}$ & $\begin{array}{l}-0.00104 \\
(0.00136)\end{array}$ & $\begin{array}{l}-0.00137 \\
(0.00113)\end{array}$ & $\begin{array}{c}-0.00228 * * \\
(0.00124)\end{array}$ & $\begin{array}{l}-0.00125 \\
(0.00109)\end{array}$ & $\begin{array}{l}-0.00293^{*} \\
(0.00174)\end{array}$ \\
\hline inflation & $\begin{array}{c}-0.0011 * * * * \\
(0.000267)\end{array}$ & $\begin{array}{l}-0.000581^{*} \\
(0.000346)\end{array}$ & $\begin{array}{l}-0.001 * * * * \\
(0.000306)\end{array}$ & $\begin{array}{l}-0.001 * * * * \\
(0.000383)\end{array}$ & $\begin{array}{c}-0.00063 * * * \\
(0.000282)\end{array}$ & $\begin{array}{c}-0.001 * * * * \\
(0.00025)\end{array}$ & $\begin{array}{l}-0.001 * * * * \\
(0.000234)\end{array}$ & $\begin{array}{l}-0.00075^{* *} \\
(0.000362)\end{array}$ & $\begin{array}{l}-0.000414 \\
(0.000405)\end{array}$ & $\begin{array}{l}-0.001 * * * \\
(0.000469)\end{array}$ \\
\hline trade & $\begin{array}{l}0.00042 * * \\
(0.000238)\end{array}$ & $\begin{array}{l}0.000564 * \\
(0.000367)\end{array}$ & $\begin{array}{c}0.000418 * * \\
(0.000757)\end{array}$ & $\begin{array}{c}0.000278 \\
(0.000274)\end{array}$ & $\begin{array}{c}0.000565 * * * \\
(0.000197)\end{array}$ & $\begin{array}{c}0.000686 * * * \\
(0.000266)\end{array}$ & $\begin{array}{c}0.00038 \\
(0.00026)\end{array}$ & $\begin{array}{l}0.000411^{*} \\
(0.000234)\end{array}$ & $\begin{array}{c}0.000635^{* * * *} \\
(0.000255)\end{array}$ & $\begin{array}{l}0.000393 \\
(0.00031)\end{array}$ \\
\hline secondary education & $\begin{array}{l}0.00138 * * \\
(0.000661)\end{array}$ & $\begin{array}{l}0.000853^{*} \\
(0.000545)\end{array}$ & $\begin{array}{l}0.00138 * * \\
(0.000663)\end{array}$ & $\begin{array}{c}0.0015^{* *} \\
(0.000764)\end{array}$ & $\begin{array}{l}0.00141 * * * \\
(0.000586)\end{array}$ & $\begin{array}{l}0.00205 * * * \\
(0.000838)\end{array}$ & $\begin{array}{c}0.00152 * * * \\
(0.000692)\end{array}$ & $\begin{array}{c}0.00131 * * * \\
(0.000568)\end{array}$ & $\begin{array}{c}0.00131 * * * \\
(0.000594)\end{array}$ & $\begin{array}{c}0.00244 * * * \\
(0.000932)\end{array}$ \\
\hline unemployment & $\begin{array}{l}0.000158 \\
(0.00192)\end{array}$ & $\begin{array}{c}0.00077 \\
(0.00222)\end{array}$ & $\begin{array}{l}0.000168 \\
(0.00194)\end{array}$ & $\begin{array}{l}-0.000632 \\
(0.00193)\end{array}$ & $\begin{array}{c}0.00147 \\
(0.00199)\end{array}$ & $\begin{array}{l}0.000698 \\
(0.00192)\end{array}$ & $\begin{array}{l}-0.000258 \\
(0.00205)\end{array}$ & $\begin{array}{l}0.000698 \\
(0.00219)\end{array}$ & $\begin{array}{c}0.00181 \\
(0.00203)\end{array}$ & $\begin{array}{l}-0.00013 \\
(0.00229)\end{array}$ \\
\hline life expectancy & $\begin{array}{l}0.00803 * \\
(0.00528)\end{array}$ & $\begin{array}{c}0.00756 \\
(0.00647)\end{array}$ & $\begin{array}{l}0.00813 * \\
(0.00489)\end{array}$ & $\begin{array}{c}0.00543 \\
(0.00666)\end{array}$ & $\begin{array}{c}0.00905 * * * \\
(0.00416)\end{array}$ & $\begin{array}{c}0.00747 * * \\
(0.00408)\end{array}$ & $\begin{array}{c}0.00605 \\
(0.00483)\end{array}$ & $\begin{array}{l}0.0119 * * \\
(0.00651)\end{array}$ & $\begin{array}{l}0.0143 * * \\
(0.00683)\end{array}$ & $\begin{array}{c}0.00349 \\
(0.00464)\end{array}$ \\
\hline domestic credit & $\begin{array}{l}-0.000466 \\
(0.000652)\end{array}$ & $\begin{array}{l}-0.001 * * * \\
(0.000463)\end{array}$ & $\begin{array}{l}-0.000463 \\
(0.000663)\end{array}$ & $\begin{array}{r}-0.000462 \\
(0.00063)\end{array}$ & $\begin{array}{l}-0.000855 \\
(0.000612)\end{array}$ & $\begin{array}{l}-0.000614 \\
(0.000624)\end{array}$ & $\begin{array}{c}-0.00036 \\
(0.000678)\end{array}$ & $\begin{array}{l}-0.000521 \\
(0.000647)\end{array}$ & $\begin{array}{l}-0.000609 \\
(0.000678)\end{array}$ & $\begin{array}{l}-0.000643 \\
(0.000524)\end{array}$ \\
\hline high-tech exports & $\begin{array}{c}0.00181 \\
(0.00146)\end{array}$ & $\begin{array}{c}0.00213 * * \\
(0.00106)\end{array}$ & $\begin{array}{c}0.00182 \\
(0.00146)\end{array}$ & $\begin{array}{c}0.00166 \\
(0.00147)\end{array}$ & $\begin{array}{c}0.00252 * * \\
(0.00121)\end{array}$ & $\begin{array}{c}0.00201 \\
(0.00154)\end{array}$ & $\begin{array}{c}0.00198 \\
(0.00136)\end{array}$ & $\begin{array}{c}0.00163 \\
(0.00151)\end{array}$ & $\begin{array}{c}0.002 \\
(0.00141)\end{array}$ & $\begin{array}{c}0.00256 * * \\
(0.0012)\end{array}$ \\
\hline tertiary education & & $\begin{array}{c}0.00252 * * * \\
(0.000951)\end{array}$ & & & & & & & & \\
\hline
\end{tabular}


voice\&accountability

political stability

govt effectiveness

regulatory quality

rule of law

corruption control
0.00111

$(0.0126)$

$-0.0135$

(0.0131)
0.0207

$(0.0157)$

-0.0231 **

(0.0119)

$0.0737 * * *$

(0.0324)

$0.057^{*}$

(0.0339)

$0.0689 * * *$

(0.0311)

$0.0565 * *$

(0.0319)

$-0.0248$

(0.0199)

$-0.0489 * *$

(0.0256)

$0.0346 \quad 0.0159$

$(0.0297)+(0.0229)$

wgi average

$0.0793^{*}$

(0.0478)

\begin{tabular}{|c|c|c|c|c|c|c|c|c|c|c|}
\hline constant & $\begin{array}{c}1.222 * * * * * \\
(0.263)\end{array}$ & $\begin{array}{c}1.961 * * * * \\
(0.491)\end{array}$ & $\begin{array}{c}1.22 * * * * \\
(0.258) \\
\end{array}$ & $\begin{array}{c}1.461 * * * * \\
(0.427) \\
\end{array}$ & $\begin{array}{c}0.948 * * * * \\
(0.288) \\
\end{array}$ & $\begin{array}{c}1.353 * * * * \\
(0.416) \\
\end{array}$ & $\begin{array}{c}1.39 * * * * \\
(0.327)\end{array}$ & $\begin{array}{c}1.109 * * * * \\
(0.452)\end{array}$ & $\begin{array}{c}0.817 * * * \\
(0.332) \\
\end{array}$ & $\begin{array}{c}1.779 * * * \\
(0.605) \\
\end{array}$ \\
\hline Observations & 187 & 156 & 187 & 187 & 187 & 187 & 187 & 187 & 187 & 187 \\
\hline R-squared & 0.204 & 0.307 & 0.204 & 0.209 & 0.253 & 0.286 & 0.21 & 0.216 & 0.228 & 0.332 \\
\hline
\end{tabular}

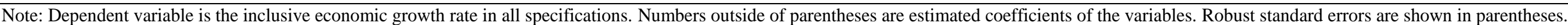
Country fixed effects are included in all specifications. * Significant at 15\%; ** significant at $10 \%$; ** significant at 5\% and **** significant at $1 \%$. 
Table 4. Reduced Form Models

\begin{tabular}{|c|c|c|}
\hline & $\begin{array}{l}\text { (1) Between } \\
1996-2007\end{array}$ & $\begin{array}{l}\text { (2) Between } \\
2008-2016\end{array}$ \\
\hline investment & $\begin{array}{c}0.00544 * * * * \\
(0.00198)\end{array}$ & \\
\hline $\mathrm{CO}_{2}$ emissions & $\begin{array}{c}-0.244 \\
(0.204)\end{array}$ & \\
\hline lagged gdp & $\begin{array}{c}-0.521 * * * * \\
(0.0494)\end{array}$ & $\begin{array}{c}-0.486 * * * * \\
(0.109)\end{array}$ \\
\hline govt. expenditure & $\begin{array}{r}-0.000212 \\
(0.00338)\end{array}$ & \\
\hline inflation & $\begin{array}{l}-0.000214 \\
(0.000371)\end{array}$ & \\
\hline trade & $\begin{array}{c}0.000573 \\
(0.000628)\end{array}$ & \\
\hline secondary education & $\begin{array}{c}0.00229 * * * \\
(0.000897)\end{array}$ & $\begin{array}{c}0.00239 * * * \\
(0.0011)\end{array}$ \\
\hline life expectancy & $\begin{array}{c}0.00616 \\
(0.00768)\end{array}$ & \\
\hline domestic credit & $\begin{array}{c}0.00078 \\
(0.00111)\end{array}$ & \\
\hline high-tech exports & $\begin{array}{c}0.00283 * * * \\
(0.00106)\end{array}$ & $\begin{array}{c}0.0057 * * * * \\
(0.00178)\end{array}$ \\
\hline tertiary education & $\begin{array}{c}0.00493 * * * * \\
(0.00134)\end{array}$ & $\begin{array}{c}0.00233 * * * \\
(0.00079)\end{array}$ \\
\hline voice\&accountability & & $\begin{array}{c}0.00393 \\
(0.00713)\end{array}$ \\
\hline constant & $\begin{array}{c}4.014 * * * * \\
(0.717)\end{array}$ & $\begin{array}{c}4.392 * * * * \\
(1.012)\end{array}$ \\
\hline $\begin{array}{c}\text { Observations } \\
\text { R-squared }\end{array}$ & $\begin{array}{l}102 \\
0.5\end{array}$ & $\begin{array}{c}65 \\
0.438\end{array}$ \\
\hline
\end{tabular}

Note: Dependent variable is the inclusive economic growth rate in all specifications. Numbers outside of parentheses are estimated coefficients of the variables. Robust standard errors are shown in parentheses. Country fixed effects are included in all specifications. * Significant at $15 \%$; ** significant at $10 \%$; *** significant at $5 \%$ and $* * * *$ significant at $1 \%$.
Table 5. Variable List

\begin{tabular}{|c|c|}
\hline Variable Name & Explanation \\
\hline investment & $\begin{array}{l}\text { Gross fixed capital formation is used as an } \\
\text { investment indicator. }\end{array}$ \\
\hline h-consumption & Household final consumption expenditure \\
\hline $\mathrm{CO}_{2}$ emissions & $\begin{array}{l}\mathrm{CO}_{2} \text { emissions are used as an } \\
\text { environmental quality indicator. }\end{array}$ \\
\hline fdi & Foreign direct investment inflows \\
\hline lagged gdp & Past period gross domestic product \\
\hline govt. expenditure & $\begin{array}{l}\text { General government final consumption } \\
\text { expenditure is used a fiscal consolidation } \\
\text { indicator. }\end{array}$ \\
\hline inflation & $\begin{array}{l}\text { Inflation rate is used as a macroeconomic } \\
\text { stability indicator. }\end{array}$ \\
\hline trade & Trade volume \\
\hline $\begin{array}{l}\text { secondary } \\
\text { education }\end{array}$ & Secondary school enrollment \\
\hline unemployment & Unemployment rate \\
\hline life expectancy & $\begin{array}{l}\text { Life expectancy at birth is used as a social } \\
\text { development and health indicator. }\end{array}$ \\
\hline domestic credit & Domestic credit to private sector \\
\hline high-tech exports & $\begin{array}{l}\text { High-technology exports are used as a } \\
\text { technological advancement and } \\
\text { technological competitiveness indicator. }\end{array}$ \\
\hline tertiary education & Tertiary school enrollment \\
\hline $\begin{array}{l}\text { voice \& } \\
\text { accountability }\end{array}$ & Voice and accountability \\
\hline political stability & Political stability and absence of violence \\
\hline govt effectiveness & Government effectiveness \\
\hline regulatory quality & Regulatory quality \\
\hline rule of law & Rule of law \\
\hline corruption control & Control of corruption \\
\hline wgi average & $\begin{array}{l}\text { Average score of six institutional quality } \\
\text { indicators' scores }\end{array}$ \\
\hline
\end{tabular}

Table 6. Country List

Algeria
Bahrain
Egypt, Arab Rep.
Iran, Islamic Rep.
Israel
Jordan
Kuwait
Lebanon
Morocco
Oman
Qatar
Saudi Arabia
Tunisia
Turkey
West Bank and Gaza
Yemen, Rep.

